DOI: https://doi.org/10.31933/dijdbm.v3i1 Received: 16 November 2021, Revised: 15 December 2021, Publish: 20 January 2022

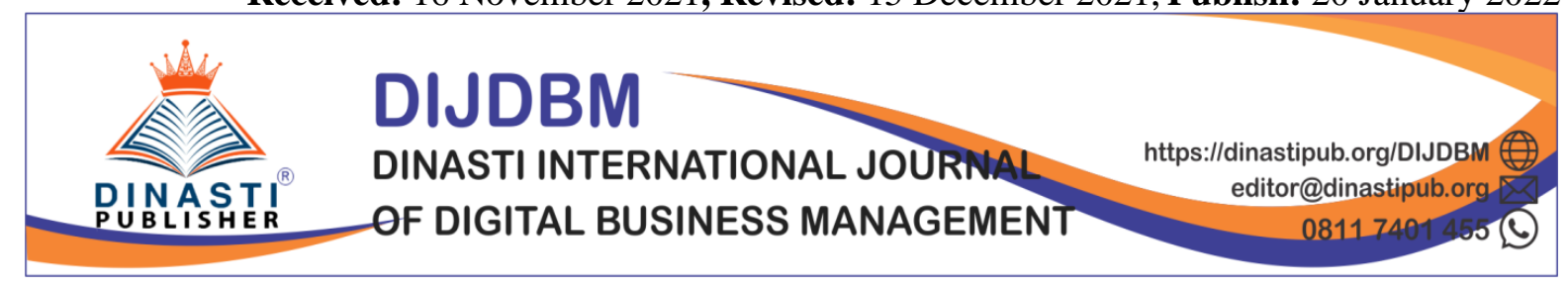

\title{
REAGAN STAR (RS) BEST DRIVER SELECTION USING MULTI FACTOR EVALUATION PROCESS (MFEP) METHOD
}

\author{
Saptono Kusdanu Waskito \\ ${ }^{1)}$ Program Studi D IV Logistik Bisnis Politeknik Pos Indonesia, Bandung
}

\section{Corresponding Author: saptonokw@yahoo.com}

\begin{abstract}
Reagan Star(RS) is a carpet distributor company that serves customers in Bandung Metropolitan. The number of customers served throughout Bandung Metroprolitan is 134 customers. Reagan Star has 5 (five) drivers who are used to distribute carpets in the Bandung Metropolitan area, namely Ali, Beni, Calsum, Dudi, Eman. The problem faced by Reagan Star is that the drivers have not provided individual performance as expected by Reagan Star, among others, often coming late to the Reagan Star office, late in delivering goods to customers, goods delivered to customers not in accordance with customers. This situation causes customer disappointment. Bandung Metropolitan. The leadership of Reagan Star originally had a plan to replace 5 (five) drivers with new drivers. The obstacle faced by the leadership of Reagan Star was that the old drivers had special customers who if the delivery of goods was not carried out by a certain driver, the customer would be reluctant to buy. the strategy of stopping the driver from becoming the driver of the Reagan Star, causing revenue from carpet sales to diminish. The Reagan Star leadership has a new strategy. The leadership organizes the selection of the best drivers. The Reagan Star leadership selects the best drivers using the Multi Factor Evaluation Process (MFEP) method. In selecting the best driver, the Reagan Star leadership determines 3 (three) dimensions that will be assessed for orderly traffic, quality of delivery of goods, and financial responsibility. In the first stage of unweighted assessment, the one who gets the highest score is Calsum. In the second study using the Multi Factor Evaluation Process (MFEP) where each dimension was assigned a weighted value, the results still determined Calsum as the winner. Many are orderly traffic, followed by the dimensions of the quality of delivery of goods, and finally financial responsibility. Conversely, if the assessment uses the MFEP method, the dimension that has the highest average value is orderly traffic, and the second is the financial responsibility variable and the last dimension is the quality of the delivery of goods. the driver starts from an orderly traffic, followed by good quality delivery of goods, followed by generating cash which is brought to Reagan Star. good quality of delivery of goods, resulting in cash which is a financial responsibility.
\end{abstract}

Keyword: Selection of the best driver, Multi Factor Evaluation Process method

\section{INTRODUCTION}

Reagan $\operatorname{Star}(\mathrm{RS})$ is a carpet distributor company that serves customers with the status of selling grocery items in traditional markets in Bandung Metropolitan, namely Bandung City, Bandung Regency, West Bandung Regency, Cimahi City and Sumedang Regency. The number of customers served throughout Bandung Metroprolitan is 134 customers. Reagan Star has 5 (five) drivers who are used to distribute carpets in the Bandung Metropolitan area, namely Ali, Beni, Calsum, Dudi, Eman. The problem faced by Reagan Star is that the drivers have not provided individual performance as expected by Reagan Star, among others, often arriving late to the Reagan Star office, late in delivering goods to customers, goods delivered 
to customers not in accordance with customers. This situation causes customer disappointment. The impact of customer disappointment is evidenced by the increasing difficulty of drivers achieving the daily targets set by the Reagan Star leadership

\section{Table 1.Target and Daily Realization of Driver}

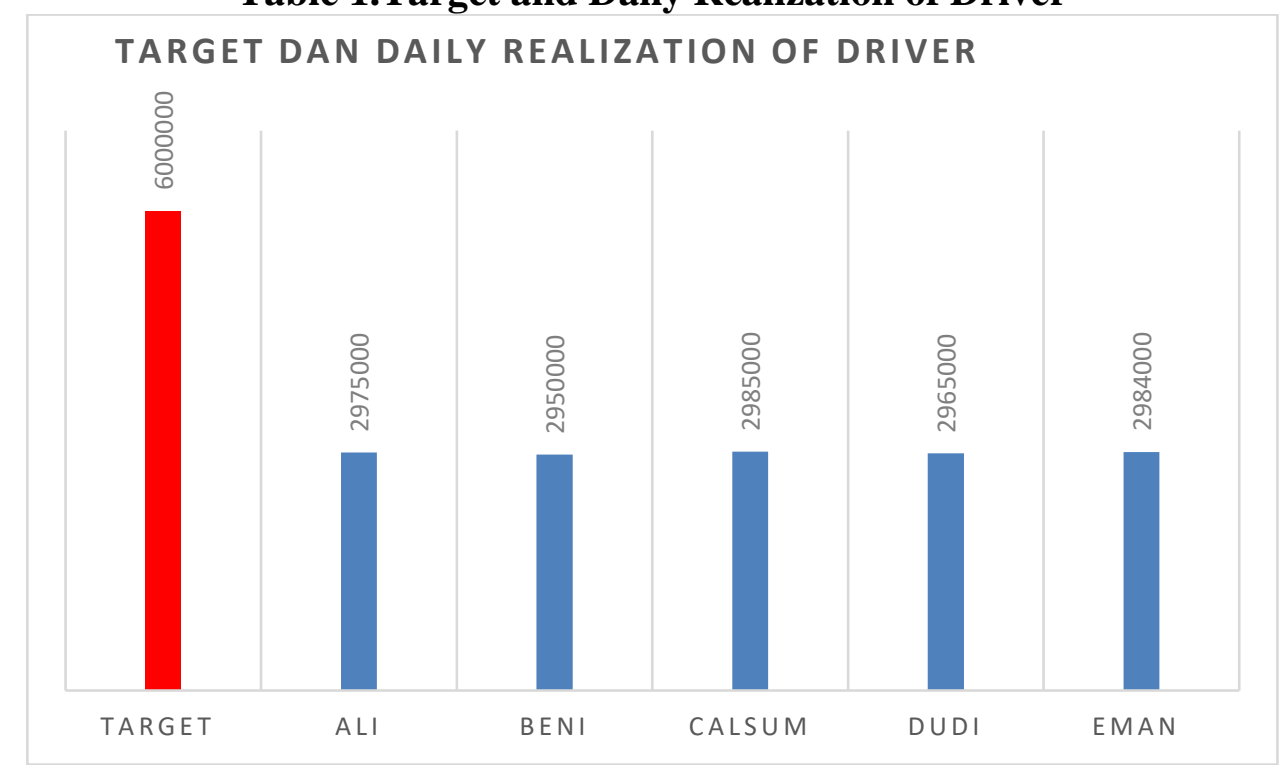

Source: Reagan Star (2022)

Usually driving a sales target of Rp. 6,000,000 is not a difficult job, but nowadays, this target is very difficult for Reagan Star drivers to achieve. Calsum only managed to bring in cash from sales of IDR 29,850,000 and was the driver with the highest sales. This raises the problem of how to improve performance. Wirawan (2020:7) explains that employee performance can be improved by selecting the best driver. The selection of the best driver will make the driver strive to improve performance to a performance that is in line with company expectations.

Referring to Wirawan's opinion (2020:7) Reagan Star carried out a strategy to improve driver performance by motivating drivers to work and producing driver performance in accordance with company expectations. The way Reagan Star held the selection of the best drivers. Reagan Star celebrates Reagan Star's 2nd Anniversary by holding a selection of the best drivers. The selection of the best drivers is determined using the Multi Factor Evaluation Process (MFEP) method.

\section{LITERATURE REVIEW Selection}

According to Wahyudi (2021: 79) selection is an activity of selecting people whose specifications are in accordance with the standards set by the company. Cascio in Wahyudi (2021: 80) explains that selection is to choose one individual in preference in others. Sikula in Wahyudi (2021: 80) ) explained that selection is a decision to choose the best person from several qualified people based on the requirements set by the company. Taking into account the opinions of experts, it can be explained that selection is an activity to choose the best person from several candidates who have met the company's requirements. The selection referred to in this study is the activity of determining the best driver from several drivers at Reagan Star, so that the selection of one driver can influence other drivers to provide good performance.

The selection of the best drivers conducted by the Reagan Star leadership was based on the best and professional driver performance criteria proposed by Fadillah (2022: 3), namely orderly traffic, quality of delivery of goods. In connection with the Reagan Star leadership also wants drivers to be able to generate cash from carpets that have been handed 
over to buyers, the authors add financial responsibility... the dimension of orderly traffic according to Fadillah (2022:4) consists of several indicators including: having a license driving, knowing the meaning of traffic signs, in 1 month have never received evidence of a traffic violation sign. According to Fadillah (2020:5) the dimensions of the quality of delivery of goods consist of several indicators of coming to the Reagan Star office on time, Departing from Reagan Star on time, Arriving at the customer's location on time, Correct type of carpet, correct number of each type of carpet, no carpet which is damaged, no carpet is missing. Jubel's opinion (2022: 4) says that a good driver in financial responsibility is a driver who is able to generate cash brought to Reagan Star as much as stated on the purchasing order form, the amount of customer debt is correct, the amount of money deposited is correct.

\section{Reagan Star Driver Performance.}

The selection of the best drivers conducted by the Reagan Star leadership was based on the best and professional driver performance criteria proposed by Fadillah (2022: 3), namely orderly traffic, quality of delivery of goods. In connection with the Reagan Star leadership also wants drivers to be able to generate cash from carpets that have been handed over to buyers, the authors add financial responsibility... the dimension of orderly traffic according to Fadillah (2022:4) consists of several indicators including: having a license driving, knowing the meaning of traffic signs, in 1 month have never received evidence of a traffic violation sign. According to Fadillah (2020:5) the dimensions of the quality of delivery of goods consist of several indicators of coming to the Reagan Star office on time, Departing from Reagan Star on time, Arriving at the customer's location on time, Correct type of carpet, correct number of each type of carpet, no carpet which is damaged, no carpet is missing. Jubel's opinion (2022: 4) says that a good driver in financial responsibility is a driver who is able to generate cash brought to Reagan Star as much as stated on the purchasing order form, the amount of customer debt is correct, the amount of money deposited is correct.

\section{Multi-Factor Evaluation Process}

This study uses the Multi Factor Evaluation Process method as a method for selecting the best driver for Reagan Star. According to Yuliantari (2018: 120) Multi Factor Evaluation Process is decision making by giving subjective and intuitive consideration to the factors that are considered important. The author determines the factors (dimensions) that are considered important are orderly traffic, quality of delivery of goods, and financial responsibility.

The Multi Factor Evaluation Process is carried out in several stages: giving weight to the factors studied, in this case 3 dimensions. Determine the most dominant factor. Comparing the value of the weights. Giving value to the indicators of each dimension studied. A value of 5 means very satisfied, a value of 4 means satisfied, a value of 3 means quite satisfied, a value of 2 means dissatisfied, a value of 1 means very dissatisfied. Provide an assessment of 5 drivers based on the criteria provided on the indicators of each factor studied. The assessment is carried out using a questionnaire whose questions are copied from the indicators of each dimension. The author calculates the total score of each driver based on the results of the assessment by the rater. The author determines who the winner is.

\section{RESEARCH METHODS}

The author in this study applied qualitative research methods. According to Sugiyono (2019: 19) explaining that what is meant by qualitative research is research based on the philosophy of positivism, used to examine the condition of natural objects, where researchers function as research tools, data collectors. Data collection is done by triangulation (combined paying attention to people's opinions in books, journals, and data in the object of research), 
the results of the research emphasize the existence of problems, and solutions to problems that arise.

\section{Types and Sources Of Data}

The data used in this study is interval data with reference to the Likert scale (Waskito, 2020: 15). The scores of 1 (strongly disgree), 2 (disagree), 3 (neutral), 4 (agree), 5 (strongly agree). The data is taken from a questionnaire that has been filled in by the respondents who have been assigned.

\section{Sampling tecnique}

This research is a qualitative research that determines all populations, namely 5 (five) drivers as the population, also designated as a sample (full sampling).

\section{Data Analysis Techniques}

Data was analyzed by Excel app

\section{FINDING AND DISCUSSION}

FINDING

\section{Weight of Each Dimension}

Table 2. Weight of Driver Performance Dimensions

\begin{tabular}{lr}
\hline \multicolumn{1}{c}{ Dimensions } & Weight (\%) \\
\hline Traffic Order & 35 \\
Quality of Delivery of Goods & 25 \\
Financial Responsibility & 40 \\
\hline Total & 100 \\
\hline
\end{tabular}

Source: Reagan Star (2022)

The Reagan Star leadership determined that the financial responsibility of the driver received the highest weight, namely $40 \%$. Quality of delivery of goods was $25 \%$, and traffic order was $35 \%$

\section{Reagan Star Driver Rating Results Without Weighting}

Table 3. Assessment of Driver Performance Without Weighting

\begin{tabular}{|c|c|c|c|c|c|c|c|}
\hline $\mathrm{No}$ & Indicator & Ali & Beni & Calsum & Dudi & Eman & Average \\
\hline A & Traffic Order & & & & & & \\
\hline 1 & $\begin{array}{l}\text { Have a Driver's License } \\
\text { Knowing the meaning of traffic }\end{array}$ & 5 & 5 & 5 & 5 & 5 & 5 \\
\hline 2 & signs & 5 & 5 & 5 & 5 & 5 & 5 \\
\hline 3 & No harm in the last 1 month & 5 & 5 & 5 & 5 & 5 & 5 \\
\hline & Amount of $\mathrm{A}$ & 15 & 15 & 15 & 15 & 15 & 5 \\
\hline $\mathrm{B}$ & Goods Delivery Quality & & & & & & \\
\hline 1 & $\begin{array}{l}\text { Arrived on time at the Reagan } \\
\text { Star Office }\end{array}$ & 4 & 3 & 5 & 4 & 3 & 3,8 \\
\hline
\end{tabular}

\begin{tabular}{|c|c|c|c|c|c|c|c|}
\hline No & Indicator & Ali & Beni & Calsum & Dudi & Eman & Average \\
\hline 2 & $\begin{array}{l}\text { Depart from PT Reagan Star on } \\
\text { time } \\
\text { Arrive on time at the customer's }\end{array}$ & 2 & 5 & 5 & 3 & 2 & 3,4 \\
\hline 3 & location & 3 & 3 & 5 & 3 & 3 & 3,4 \\
\hline
\end{tabular}


The type of carpet submitted is

\begin{tabular}{|c|c|c|c|c|c|c|c|}
\hline & correct & 4 & 3 & 4 & 5 & 3 & 3,8 \\
\hline & The carpet is not damaged & 2 & 5 & 5 & 5 & 3 & 4 \\
\hline \multirow[t]{2}{*}{6} & No carpet is missing & 5 & 3 & 4 & 5 & 4 & 4,2 \\
\hline & Total B & 20 & 22 & 28 & 25 & 18 & 3,77 \\
\hline \multirow[t]{5}{*}{$\mathrm{C}$} & Financial Responsibility & & & & & & \\
\hline & Cash equals Purchasing Order & 2 & 2 & 4 & 3 & 3 & 2,8 \\
\hline & $\begin{array}{l}\text { The amount of money owed is } \\
\text { true }\end{array}$ & 2 & 4 & 5 & 4 & 4 & 3,8 \\
\hline & Cash equals sales -debt & 2 & 3 & 4 & 4 & 3 & 3,2 \\
\hline & Total C & 6 & 9 & 13 & 11 & 10 & 3,27 \\
\hline $\mathrm{D}$ & Total $\mathrm{A}+\mathrm{B}+\mathrm{C}$ & 41 & 46 & 56 & 51 & 43 & 4,01 \\
\hline
\end{tabular}

Source : Reagan Star (2022)

Reagan Star Driver Assessment Results Using the MFEP Method

Table 4. Assessment of the Best Driver Using the MFEP Method

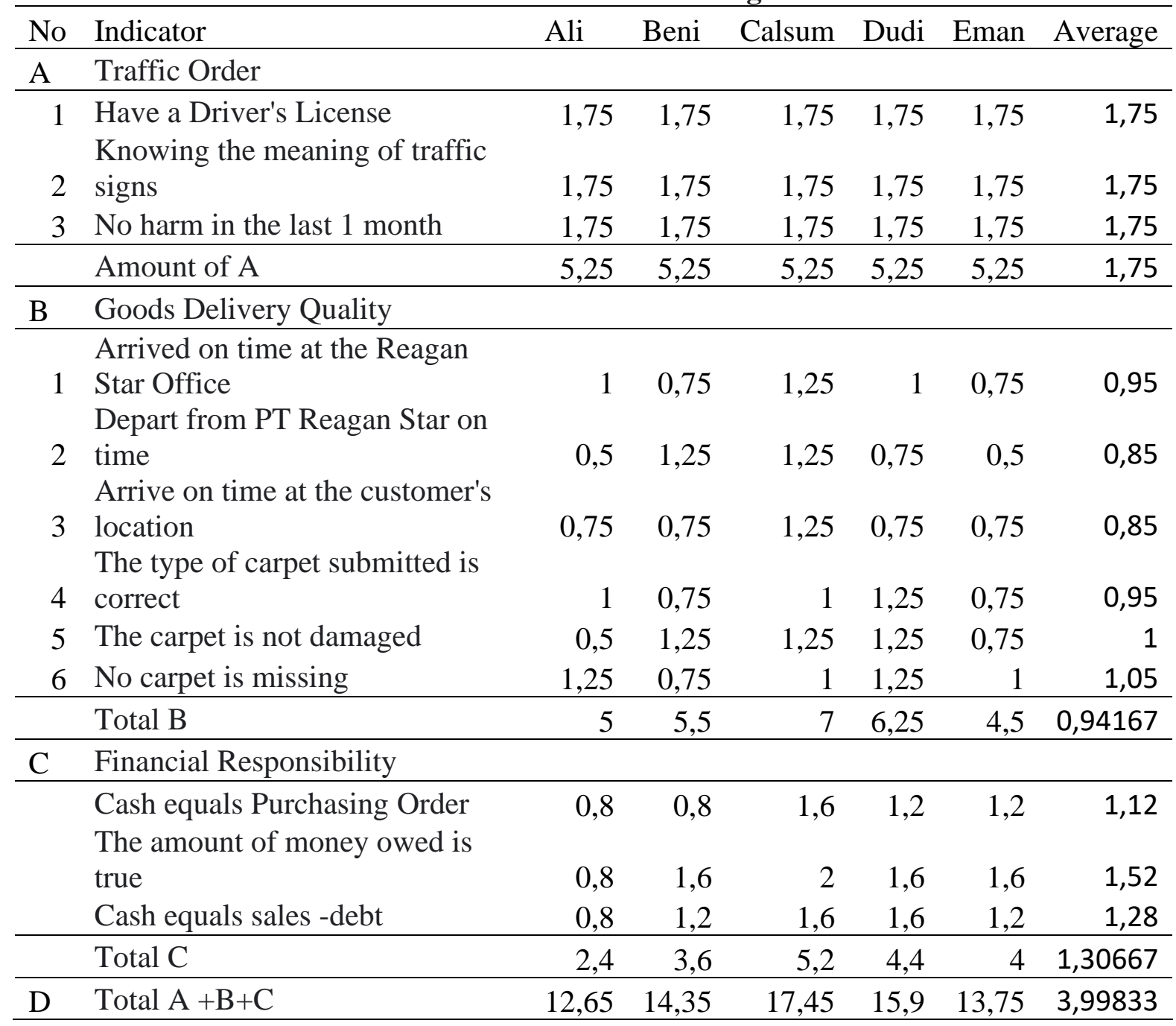

Source : Reagan Star (2022)

Referring to the opinion of Yuliantari (2018: 120) the Multi Factor Evaluation Process requires researchers to carry out weighting, then the data in table 3 must be weighted by means of the value of each indicator and the value of each dimension is multiplied by the weight of each dimension. The value of traffic order is multiplied by the weight of $35 \%$, the value of the 
quality of delivery of goods is multiplied by the weight of $25 \%$ and the value of financial responsibility must be multiplied by the weight of $40 \%$. The results of the weighting of the data in table 3, resulted in the assessment of the best driver at the Reagan Star company according to the Multi Factor Evaluation Process (MFEP) method as presented in table 4.

The assessment using the MFEP model weighting determines that Calsum as the driver has a score of 17.45 and is the highest score of the other drivers. I The dimension with the highest average value after weighting is traffic order. The smallest value was achieved by the dimension of the quality of delivery of goods with an average value of 0.94167 .

\section{DISCUSSION}

The winner as the best driver is Calsum because both based on an unweighted assessment and the MFEP method, Calsum gets the highest score. Actually, the results of the research are enough to determine that Calsum as the driver who gets the most points and gets the title of the best driver according to the assessment of the leadership of Regan Star. There is something interesting to observe, namely the dimension winner who gets the second and third largest scores has different results between calculations without using weights and calculations using the method weighting (Multi Factor Evaluation Process)

\section{Unweighted Calculations}

The results of the calculation without weighting produce a sequence of dimensions from the order of the largest value to the smallest, namely the dimensions of orderly traffic, orderly delivery of goods, financial responsibility with average values of 5 and 3.77 and 3.27 respectively. . So that what must be corrected first is the dimension that obtains the smallest average value, then the dimension that must be corrected first is the financial responsibility of the driver who obtains an average value of 3.27 because the average value is the average value obtained. The minimum repairs are carried out by training drivers so that before handing over the goods, it is ensured that the customer pays in cash, otherwise the goods in the form of a carpet should not be handed over to the customer, and brought back to Reagan Star. Drivers are trained that the amount of goods delivered is only the amount of cash given by the customer

\section{Calculations Using the Multi Factor Evaluation Process}

The results of calculations using the Multi Factor Evaluation Process method or the weighting method produce that the highest average dimension value is the traffic order dimension with an average value of 1.75 and the average value of the dimensions of the quality of delivery of goods is 0.941 and is the average value. lowest average. In connection with the lowest average value is the quality of the delivery of goods, it is better that what must be improved is the quality of the delivery of goods. The way to improve the quality of delivery of goods is to train the driver so that the driver tries his best to come to the Reagan Star location on time, departs from the Reagan Star location to the customer's location on time, arrives at the customer's location on time, the type of goods delivered is in accordance with what was ordered by the customer, the carpet is not damaged, the carpet is not lost. The leadership of Ragan Star must punish drivers who make mistakes and give rewards when the driver produces performance that meets the target

\section{Merger}

The author combines 2 (two) results of the calculation of the driver's performance assessment, both those that do not use weighting and those calculated using the Multi Factor Evaluation Process method (using weighting). and financial responsibility. Using the Multi Factor Evaluation Process method, it was obtained data that the dimension that obtained the highest average value was the dimension of orderly traffic followed by financial responsibility and the average value of the smallest dimension was the quality of delivery of goods. 
Combining the 2 findings, it can be agreed that the driver's performance starts with orderly traffic, followed by good quality delivery of goods, followed by generating cash which is brought to Reagan Star. An orderly traffic will be able to deliver goods with good delivery quality, thus generating cash which is a financial responsibility.

\section{CONCLUSION AND RECOMMENDATION Conclusion}

Based on the calculation of the average value using both the unweighted method and using the Multi Factor Evaluation Process method (by weighting), it was informed that Calsum was determined as the best driver for Reagan Star because it had the highest average score.

If it is calculated without weighting, then the dimensions that have the highest average value begin with orderly traffic, quality of delivery of goods, financial responsibility. If calculated using the Multi Factor Evaluation Process method (using weighting), then the dimensions that have an average value The best average starts from orderly traffic, financial responsibility, quality of delivery of goods.

The results of the study establish a new research model that the driver's performance starts from a driver who is orderly in traffic will be able to deliver goods with good delivery quality, thus generating cash which is a financial responsibility.

\section{Recommendation}

Due to the fact that there are still 4 (four) drivers who have not met the expectations of the Reagan Star owners, the author suggests that the Reagan Star leadership should make some improvements to the dimensions of financial responsibility and the dimensions of the quality of delivery of goods by:

1. Improvements in the Dimensions of Financial Responsibility

The repairs were carried out by way of the driver being trained so that before handing over the goods, it was ensured that the customer paid in cash, otherwise the goods in the form of a carpet should not be handed over to the customer, and brought back to Reagan Star. Drivers are trained that the amount of goods delivered is only the amount of cash given by the customer

2. Improvements in the Dimensions of the Quality of Delivery of Goods

The way to improve the quality of delivery of goods is to train the driver so that the driver tries his best to come to the Reagan Star location on time, departs from the Reagan Star location to the customer's location on time, arrives at the customer's location on time, the type of goods delivered is in accordance with what was ordered by the customer, the carpet is not damaged, the carpet is not lost. The leadership of Ragan Star must punish drivers who make mistakes and give rewards when the driver produces performance that meets the target

\section{BIBLIOGRAPHY}

Sugiyono. (2019). Metode Penelitian Kuantitatif. Bandung: Alfabeta.

Suwatno. (2017). Manajemen SDM. Bandung: Alfabeta.

Wahyudi. (2021). Manajemen Sumber Daya Manusia. Bandung: Sulita.

Waskito. (2020). Terampil Mengolah Data Statistik Pakai SPSS dan AMOS. Bandung: Alfabeta.

Yulyantari. (2018). Mnajemen Model Pada Sistem Pendukung Keputusan. Yogyakarta: Andi Offset. 